UDC 007:304:659.13

\title{
PARTICULARITIES OF VISUAL METAPHORS IN ADVERTISING CAMPAIGNS ABOUT ECOLOGICAL PROBLEMS
}

\author{
ANTONOVA Olha, \\ PhD (Social Communications), Associate Professorat, e-mail: antonova.olga.edu@gmail.com; \\ SOKOLOV Maksym, \\ Magistrant, e-mail: max.sokolov@gmail.com; \\ National University of Food Technologies, 68, Volodymyrska St., Kyiv, 01601, Ukraine.
}

The article is dedicated to the peculiarities of visual metaphors usage in the design of foreign public service announcement campaigns about ecological problems. The specifics of graphic and expressive means of public service announcements against the destruction of forest resources is analysed, typical types of visual metaphors used in public service announcement materials in campaigns of WWF and other world public organizations about this topic are distinguished. It was found that the main implementation element of authors' communicative strategy in public service announcement materials is the graphic part of advertising, which is based on a metaphorical understanding of reality, and the text serves as an explanatory addition to it. Visual content can be largely outspoken, cruel, and appealing to guilt and fear, which ensures the impact of suggestive influence of public service announcement products and serves as a factor of effectiveness for a public service announcement campaign about this problem.

Key words: visual metaphor, graphic and expressive means of public service announcement, influence of public service announcement, creolized text, design of advertising.

\section{ОСОБЛИВОСТІ ВІЗУАЛЬНОЇ МЕТАФОРИКИ В ДИЗАЙНІ РЕКЛАМНИХ КАМПАНІЙ НА ЕКОЛОГІЧНУ ТЕМАТИКУ}

Статтю присвячено розгляду особливостей використання візуальной метафорики в дизайні соціальноӥ реклали на екологічну телатику закордонних реклалних калпаній. Проаналізовано специфіку зображально-виражальних засобів реклали проти винищення лісових ресурсів, виокреллено типові види візуальних метафор, використаних у реклалних матеріалах кампаній WWF та інших світових громадських організацій на ию телу. З'ясовано, що основнил елелентол-реалізатором комунікативної стратегї авторів у рекламних матеріалах є зображальна частина реклали, яка грунтується на метафоричнолу ослисленні дійсності, а текст слугує пояснювальнил доповненням до неї. Візуальний контент може бути значною мірою відвертил, жорстоким, апелювати до почуття провини й страху, що забезпечує впливогенність реклалних продуктів та є фактором ефективності рекламной калпанї, яка стосується зазначеної проблеми.

Ключові слова: візуальна метафорика, зображально-виражальні засоби реклали, впливогенність реклали, креолізований текст, дизайн реклали.

I

ntroduction. The current stage of humankind existence, marked by large-scale environmental, social, medical problems, necessitated the formation of a person with an active civic position, aware of the epoch challenges and with a set of effective tools for shaping optimal social behaviour.

Public service announcement is meant to serve this purpose, because its mission, as noted by O. Lavryk, is «to change the behavioural model of society. Public service announcement is an effective mean of fighting against social evil. It changes people's attitude to everyday reality, then behaviour changes, and new social values are formed" [8, p. 71]. According to D. Oltarzhevskyi, public service announcement «can be considered as a system of specific propaganda communications of informational nature, ... an independent social and communicative function aimed at meeting the needs of people in relevant social information" $[11$, p. 35].

(C) Антонова О., Соколов М., 2021 
Topicality. One of the acute problems of our time, which needs an urgent response, is the unregulated destruction of the world's forest resources. This is caused by several factors. Firstly, the role played by the totality of forests for the entire planet is extremely important. Forests also play a significant role in the normalizing of threatening environmental processes, in particular as a key factor of climate change lessening and carbon absorption. Therefore, forest conservation is particularly important in the conditions of the rapid worsening of global warming problem during the last decade.

Secondly, one should note the swiftness with which the forest system is currently being destroyed and degraded due to unreasonable or illegal logging and fires. According to researchers, the annual deforestation in the world is estimated at 13.7 million hectares per year, equal to the area of Greece. In this case, only half of this area is compensated by planting new or regenerating existing forests. Therefore, if the current rate of deforestation maintains, by 2030 we will lost about $80 \%$ of the most ecologically important forest landscapes on the planet [16].

The severity of the problem causes its active coverage in the materials of global public service announcement campaigns, so their number and international nature determine the topicality of our study. Of interest are those means of influence, in particular, metaphors that are used to implement the communication strategy of public service announcement campaigns. Because of the global nature of the problem, the need to convey information about the environmental situation to the widest possible audience, the means of expression and imagery against deforestation should be universal, easy to decode, but emotionally rich and highly influential. However, so far the implementation peculiarities of communicative strategy through graphic metaphors in the advertising of this thematic group as a holistic semantic complex and the tendency to visualize the problem of deforestation have not been the subject of research. This determines the novelty of our study.

The aim of our research is to investigate the particularities of figurative and expressive means of public service announcement campaigns against the destruction of forest resources, to identify typical types of visual metaphors used in such materials on this topic, and to disclose their influential potential.

The realization of the defined aim involves solving several tasks: to outline the concept of creolized advertising text; to determine which of its components has a leading role in the authors\&\#39; communicative strategy implementation in the array of public service announcements about forest conservation; to single out typical metaphorical concepts of the visual component in public service announcements on this topic and to trace the tendencies in their visual realization.

The object of the study is the materials of the public service announcement campaigns of WWF and other world civil organizations, dedicated to the problem of deforestation and to the need to preserve the forest resources of the planet. The subject was the peculiarities of the visual metaphors use for the implementation of the campaign communicative strategy.

When considering the features of visual metaphors in public service announcement materials on the problem of deforestation, we relied on the concept of creolized text as a holistic combination of visual and verbal components, which was developed by V. Berezin, A. Bernadska, and Yu. Sorokin. A. Anikaieva's and H. Tsukanova's investigations are devoted to the study of visual metaphors in advertising and to the peculiarities of their interaction with a textual component. The role and functions of public service announcements in general and the influence of expressive means in such materials are investigated in the works D. Oltarzhevskyi, O. Lavryk, T. Zhalko, and O. Muliar. However, the particularities of metaphorical understanding of reality and the influential potential of visual metaphor in public service announcements about environmental problems have not been studied in detail by scientists. 
Research methods. General scientific methods of analysis and synthesis were used for the research. Attention was focused on the graphic component of the materials presented in the public service announcements devoted to the problem of deforestation. Thus, content analysis was implemented to review used visual means and to identify trends in the visualization of environmental problems in public service announcement materials. Descriptive method allowed distinguishing units of analysis and classifying them. Component analysis and comparative analysis allowed to identify types of visual metaphors in public service announcements and to compare them by degree of frankness, and emotional component.

Research results. Drawing public attention to the difficult situation in which forests are now, forming in the minds the idea of everyone's involvement in the situation such tasks are taken by advertising campaigns for the conservation of forest resources on the planet. Informing, focusing the attention of the mass audience on a particular problem is a fundamental task, the basic stage of implementation of the public service announcement communicative strategy $[14, \mathrm{p} .70]$.

The leading initiator of public service announcement campaigns against deforestation in the world is the WWF (World Wide Fund for Nature), an international nongovernmental organization involved in nature conservation, research and restoration. The task of the World Wide Fund for Nature, which operates in more than 100 countries, is to raise people's awareness of environmental degradation and call for support for the preservation of the natural environment. Materials of public service announcements created under the auspices of WWF are widely circulated in the press, on internet portals and on television.

The problem of the planet deforestation, because of its relevance and international status, has repeatedly been the subject of public service announcement campaigns conducted in some particular countries, and worldwide. In addition, the figurative and expressive means used to transfer the idea of public service announcement message, their universality, influential potential attract attention.

At the heart of the influence of public service announcement materials lies a metaphorical understanding of reality, which scientists consider «the shortest way to the subconscious» $[18, \mathrm{p} .141]$. It is formed by both verbal and nonverbal visual components. The so-called creolized text is formed, which is a special linguistic visual phenomenon, «a complex textual formation in which verbal and nonverbal components form one visual, structural, semantic and functional unity, which provides its complex pragmatic influence on the addressee" [3, p. 17]. In this case, the word component (verbal) can be represented by a title, caption or slogan, and non-verbal - by photos, illustrations, infographics [13, p. 150]. As I. Tsukanova notes, «all or only some components of a creolized advertising text can be metaphorical, but its true essence can be understood only if all components are united» [13, p. 150].

More often in public service announcement about the protection of forests the image component, based on a visual metaphor, plays the role of the main carrier of the message, and the text helps to decode it and strengthens the influential potential. Visual metaphor «is built in the comparison of two visual images that act as iconic signs, identified with certain objects of representation. When they are assembled together, the meaning that is formed is interpreted as a symbol or allegory of such a phenomenon, which may not be directly related to each of the presented images» [13, p. 151]. This is exactly the figurative comparisons that help the authors of the advertising message to deliver their opinion to the audience in an original and convincing way, to make it original and memorable, as well as easily interpreted by the public through appealing to images of an international nature.

Thus, one of the most popular metaphorical comparisons is the comparison of the natural environment with the human body. The issue of preserving one's own health 
and security of one's own existence is one of the basic needs of every human being, so public service announcement that appeals to this image is convincing, as it visualizes the postulate as much as possible: «Taking care of nature means taking care of your life.» This comparison was a base for a well-known creative sample about deforestation proposed by the WWF in 2008. A creative image meant to remind people of the importance of trees to the atmosphere was used in an public service announcement campaign developed by the French agency TBWA to raise public awareness of deforestation [4].

In the used visual materials, the image of the forest is incarnated through the shape of human lungs. Rivers flow through the forests, symbolizing veins and arteries. One lung looks healthy, while the other was damaged by deforestation. Thus, there is a visualization of the established metaphor "forests are the green lungs of the planet." This emphasizes the importance of forests to support the lives of both the planet and humanity.

The comparison of a forest and a human body is based on the similarity of the functions they perform. Lungs are the organ that supplies oxygen to a human body just as a forest provides oxygen production for the entire planet. Just as lung damage can lead to poor health and death, annihilation of trees and uncontrolled deforestation can lead to environmental degradation and destruction of the entire ecosystem. The result of this metaphor implementation is «strengthening emotional connections... where little emotional connection exists naturally» [7, p. 123], helping recipients to become aware of the interconnectedness of their own lives and forest conservation.

The same comparison, but used for a different purpose, we see in another WWF public service announcement, which depicts a human hand with a cut off finger, instead of which one can see a tree trunk. The slogan of the public service announcement campaign explains this metaphor to the audience: "We cut off what will not grow again» [9]. In other public service announcement images in the series, tree trunks become a cut off extension of a human hand or neck [9]. Just as there are no ways to restore lost body parts, it is impossible to revive the Amazon rainforests that have been damaged by deforestation. The transfer of the organs properties of the body to the image of the forest in this case no longer indicates the vital need of forests for salvation, but serves to visualize the idea of non-renewability, the risk of final loss of natural resources.

Another common comparison that is used as a base for the metaphorization of the forest image in public service announcements against its destruction is the direct identification of forest existence (visually embodied in the image of a tree) with existence of animals. Since man is more inclined to empathize with living, concretely represented beings than with a collective phenomenon with a much greater degree of abstraction, which in the mass consciousness is a forest, such a visual metaphor is influential and effective.

This analogy is the base for candid and tough public service announcement created by the Sanctuary agency. In the original, the slogan of the public service announcement campaign sounds like «Whenthewoodsgo, wildlifegoes», which translates as "When the trees go, so does the wildlife» [1].

The images show rather cruel scenes of beheading of cheetahs, birds, gorillas and snakes at the same time as cutting down trees. With rapidly growing globalization and demand for goods, the impact on the environment is killing its inhabitants. As the environment collapses, so does the life that comes with it. The public service announcement campaign emphasizes that commercialization and consumption are absorbing the planet's resources and reducing wildlife habitats, causing small species to become extinct one after another. The authors of the analysed public service announcement call each of the viewers to minimize personal consumption and independently explore how to save wildlife - these are the first steps to be taken.

In this case, the main influential potential is the image itself. Because of its frankness, even cruelty, it evokes an emotional response in the audience. The verbal part 
of this public service announcement as of a creolized text, represented by a slogan, is intended to facilitate the interpretation of the image, but is auxiliary, as indicated by the compositional organization of announcement. The slogan is written in small letters, located in the lower right corner of the image, which grabs and holds the eyes of the audience.

The public service announcement campaign created by DPZ\&T for the SOS Mata Atlântica Foundation, which fights for the preservation of Brazil's forests, is similar in metaphorical interpretation. The prints of the series depict a jaguar and a monkey, whose bodies have half turned into skeletons, symbolizing the gradual extinction of fauna [12]. The slogan "A forest never dies alone» helps to interpret the images, which indicates that along with the destruction of trees, the inhabitants of the forest are also being destroyed. The rather candid depiction of animals suffering from the deforestation of the Amazon in these public service announcement posters «revives» the problem, translating it from the category of resource destruction to the category of a murder.

TBWA's «It's Not Just a Tree» public service announcement [5] is based on the same comparison of forest existence and its inhabitants, but is much less cruel than those posters discussed above. The authors of the public service announcement campaign used a refined visualization of the problem, by representing the main idea through the image of tree sawing, when the texture of annual rings, cracks, veins on tree end form the image of an animal (gorilla, owl, tiger). Thus, the idea that behind every destroyed tree stands the destruction of the fate of forest inhabitants was made visible. Because of the visual features of representation, the images of animals are not obvious, they require careful consideration and «finding". On the one hand, this becomes an additional symbolic touch that complements the idea of posters that the full extent of the deforestation tragedy and its consequences are not always visible at first glance, they need to be studied and paid attention to. On the other hand, this kind of game with the recipient, encouraging him to "decode the riddle» announced by the slogan on the poster, becomes an element of the authors' influential strategy, forces to spend more time reading the poster and strengthens its memorability.

A public service announcement campaign developed by the Brazilian agency Paz Comunicação Estratégica is close to it in metaphoric system and sophistication of visual means of expression [2]. Its central object is the image of a dry leaf, on which the silhouettes of animals in their natural environment are carved (for example, an owl, and a fallow deer). The expressive textured surface of the leaf, the perfection of the executed carving, the similarity to the objects of art projects - all this attracts the attention of viewers and encourages to look at the image in detail, to admire its aesthetic qualities. Due to its positive suggestion, focusing not on «intimidation", but on bringing aesthetic pleasure, this public service announcement campaign differs from others in similar topic and does not cause subconscious rejection, in contrast to more brutal public service announcement posters. The campaign slogan is «Much more than trees. Save» helps to explain the semiotic meaning of the image, formulates the main idea of the campaign and its imperative.

Public service announcement materials created by the advertising agency «LeagasDelaney» for a campaign called «Plants for the Planet» are visually similar to the Brazilian public service announcements [10]. Here, too, the central image is a leaf with a carved pattern. However, the conceptual content is completely different. Public service announcement posters visualize the forest not as a habitat for fauna, but as a kind of filter that helps to combat the global environmental problem of air pollution because of human activities, and thus preserves the life and comfortable existence of society. For example, the outlines of cars or airplanes that produce large amounts of carbon dioxide or the contours of factory pipes from which poisonous smoke emits are cut out on a green leaf [10]. In this way, the recipients form a stronger emotional reaction 
- they are reminded of several problems, each of which is directly related to human life and activity.

General simplicity and conciseness of the means of expression are also worth noting. Bright pure and natural colours attract the eye (green leaf colour, even white background), a few words throughout the poster that explain the idea-nothing distracts from the main idea of the public service announcement campaign. Due to the lack of complex, fantasy images, the picture looks like a direct conversation with the viewer. This is facilitated by the desire for reality in public service announcement: the image of the leaf is clear, recognizable; it seems that it has not undergone graphic processing, and the drawing is cut by hand. This public service announcement is easily decoded by a wide audience.

The multi-layered metaphor formed the basis of the poster series for the British public service announcement campaign «Homeless Animals» in 2010, created by WCRS Limited for the organization Born Free Foundation [17]. The authors used images of animals from one of the best international photographers, George Logan, to illustrate the plight of hundreds of thousands of endangered animals displaced from their homes by human activities, including deforestation and ill-considered agriculture.

In the public service announcement posters of this campaign, animals appear in the image of homeless people seeking refuge on the polluted streets of cities. In fact, the image of the forest is not visually represented in the pictures; its fate is figuratively indicated by the location of animals, which, in turn, acquire the visual features of stray people who have been left homeless. For example, a family of gorillas and a lioness with lion cubs are sitting on a painted graffiti street, holding a poster informing them that they, like thousands of others, have lost their homes due to deforestation [17].

Will Travers, CEO of Born Free Foundation, said: «These are quite amazing and difficult images that confront people with the reality of what we do collectively with the natural world. They force each of us to re-evaluate our personal impact on the future of endangered species» [17].

Wild animals are depicted in urban settings to make an eloquent reminder that wildlife is losing its habitat at an alarming rate. All costs related to this public service announcement campaign, including advertising space and printing, were fully covered by the Born Free Foundation [17].

Anne Tudor, director of marketing for the charity, said: «People living in our cities have a hard time imagining what life is like for homeless wildlife. Six images in the new Born Free «Homeless» campaign, combining wildlife with the urban landscape, put their situation in a more familiar context. We hope that when people see a bear seeking shelter in a devastated doorway, or a lone elephant surrounded by construction debris, they will be able to resonate with the critical problem behind the images and encourage themselves to take action» [17].

Also in social public service announcements against deforestation, such metaphorical tool as hyperbole is actively used. For example, a public service announcement poster from the Thai branch of Ogilvy \& Mather advertising agency (a part of the public service announcement campaign "Forests for Life» in 2007) depicts a huge area of completely destroyed forest with only one tree left. Beneath it, one can see people trying to hide from the scorching sun [6].

The image of hyperbolized large-scale destruction of trees makes viewers worried and afraid. Such negative emotions are often used in social marketing (non-commercial marketing) to appeal to people who must meet social norms, as they have been shown to be more effective than positive emotional appeals [15, p 88]. This public service announcement has a high impact potential, creating an emotional imbalance or discomfort so that viewers are motivated to behave properly, raising awareness about deforestation to reduce these feelings. 
Conclusion and perspectives. As a result of the research, the peculiarities of communicative intention realization through visual metaphors in the array of public service announcements against forest resources destruction are determined; in particular, typical types of visual metaphors used in advertising materials on this topic are singled out; their influence potential is outlined.

Based on the analysis of foreign public service announcement campaigns against deforestation, we found out that the basis of the advertising materials influence is a metaphorical understanding of reality, which is formed by both verbal and nonverbal, visual components. Thus, a creolized text is formed, in which the main elementimplementer of authors' communicative strategy is the graphic part of advertising, which is based on a metaphorical understanding of reality, and the text serves as an explanatory addition to it. Typical metaphors in such public service announcements are the comparison of the forest and the human body, the comparison of the forest's existence and the life of its inhabitants, as well as the hyperbolized visualization of the consequences of its destruction.

The characteristic features of reality comprehension through visual metaphors in advertising materials on this topic and their suggestive particularities are determined. Visual content in public service announcements against deforestation is marked by openness, even cruelty, it does not moderate, but rather exaggerates the visual images of the negative consequences of deforestation. Figurative and expressive means of visual nature, supported by a textual component, create a negative prognostic image of the future, appeal to guilt and fear, which ensures the impact of advertising products and is a factor of effectiveness for advertising campaigns about the problem.

The novelty and practical meaning of the study are defined by the topicality of public service announcements against deforestation in the world and, at the same time, are important because of insufficient representation of this problem through public service announcements in the domestic information space. The results of our research can be used by the Ukrainian advertising experts specializing in environmental public service announcements so they can further rethink the world's heritage and trends in the creation of visual content on this topic.

The comparison of visual expressive means and suggestive particularities of graphic metaphors in negative advertising and advertising with a positive focus on ecological problems could be the topic of further research.

1. Adeevee (2014), «Sanctuary: Wildlife», avaliable at: http://www.adeevee.com/2014/12/ sanctuary-wildlife-print/ (accessed 05 April 2021).

2. ADS of the Word (2011), «Much more than trees», avaliable at: https://www.adsoftheworld. com/media/print/so_acao_much_more_than_trees_2 (accessed 05 April 2021).

3. Anisimova, E.E. (2003), Linguistics of the text and intercultural communication (based on creolized texts), Akademiia, Moscow, $128 \mathrm{p}$.

4. Billard, L. (2008), «WWF / TBWA Paris», avaliable at: https://leopoldbillard.com/WWF (accessed 05 April 2021).

5. Bright Side (2019), «18 New Social Ads That Are So Powerful, They Can Hit You Like a Lightning Bolt», avaliable at: https://brightside.me/creativity-design/18-new-social-ads-thatare-so-powerful-they-can-hit-you-like-a-lightning-bolt-709360/ (05 April 2021).

6. Communication arts (2016), "Wwf Forests For Life poster», avaliable at: https://www. commarts.com/project/16834/wwf-forests-for-life-poster (accessed 05 April 2021).

7. Delbaere, M. (2011), «Personification in advertising», Journal of Advertising, no. 40, pp. 121-130.

8. Lavryk, O.V.(2008), «Public service announcements in the modern media space: to definition of the concept», Uchonyie Zapiski Krymskoho Federalnoho Universiteta Imeni V.I. Vernadskoho. Filolohicheskiie Nauki [Scientific Notes of V.I.Vernadsky Crimean Federal University. Philological Sciences ], no. 1, pp. 65-70. 
9. Lewicki, S. (2012), "WWF Regenwald», avaliable at: http://www.klassefuerideen.at/ WWF-Regenwald.52.0.html?\&L=1 (accessed 05 April 2021).

10. Matthews, F. (2012), «The Advertising Campaign for Plant for the Planet», avaliable at: https://freeyork.org/creative/the-advertising-campaign-for-plant-for-the-planet/ (accessed 05 April 2021).

11. Oltarzhevskyi, D.O. (2016), Public Service Announcements, Tsentr vilnoi presy, Kyiv, 120 p.

12. Osocio.org (2017), «The forest never dies alone», avaliable at: https://osocio.org/message/ the-forest-never-dies-alone/ (accessed 05 April 2021).

13. Tsukanova, H.O. (2013), «Metaphor in creolized texts of print public service announcements», Derzhava ta Rehiony. Sotsialni Komunikatsii [State and Regions. Social Communications ], no. 2, pp. 150-154.

14. Tymoshenko, A.L. (2006), "Public service announcements in Ukraine: analysis of the impact on the formation of young people's positive behaviour», Ukrainskyi sotsium [Ukrainian Society], no. 2, pp. 69-77.

15. Wheatley, J. J. (1970), «The relationship between anxiety and positive and negative advertising appeals», Journal of Marketing Research, no. 7, pp. 85-89.

16. World Wildlife Fund (2015), Living Forests Report Chapter 5: Saving Forests at Risk, Switzerland, 52 p., avaliable at: https://www.worldwildlife.org/publications/living-forestsreport-chapter-5-saving-forests-at-risk (accessed 05 April 2021).

17. Writer, S. (2010), «Born Free launches hard-hitting homeless animal campaign», avaliable at: https://www.thedrum.com/news/2010/04/29/born-free-launches-hard-hitting-homelessanimal-campaign (accessed 05 April 2021).

18. Zhalko, T., Muliar, O. (2020), «Metaphorical figurativeness as a component of advertising creativity». Aktualni Problemy Suchasnoi Osvity ta Nauky v Konteksti Yevrointehraccessed atsiinoho Postupu: Materialy VI Mizhnarodnoi Naukovo-praktychnoi Internet-Konferentsii, Prysviachenoi 20-tyrichchiu Instytutu (m. Lutsk, 21-22 Travnia 2020 Roku) [Topical Problems of Modern Education and Science in the Context of European Integration Progress: Materials of the VI International Scientific and Practical Internet Conference Dedicated to the 20th Anniversary of the Institute (Lutsk, May 21-22, 2020)], Vezha-Druk, Lutsk, pp. 141-144.

УДК 007:304:659.13

\title{
ОСОБЛИВОСТІ ВІЗУАЛЬНОЇ МЕТАФОРИКИ У ДИЗАЙНІ РЕКЛАМНИХ КАМПАНІЙ НА ЕКОЛОГІЧНУ ТЕМАТИКУ
}

\author{
Антонова Ольга, канд. наук із соц. комунік., доц., е-mail: antonova.olga.edu@gmail.com \\ Orcid ID: https://orcid.org/0000-0003-3213-8699 \\ Соколов Максим, магістрант, e-mail: max.sokolov@gmail.com \\ Orcid ID: https://orcid.org/0000-0001-6042-2377 \\ Національний університет харчових технологій, вул. Володимирська, 68, м. Київ, 01601, Україна.
}

Вступ. Статтю присвячено розглядові особливостей використання в дизайні соціальної реклами закордонних рекламних кампаній на екологічну тематику візуальної метафорики. Саме соціальна реклама перебирає на себе функції регуляції й формування бажаної суспільної поведінки. Важливість проблеми зумовлена активним висвітленням їі у соціальній рекламі світових кампаній. Їх кількість та міжнародний характер зумовлюють актуальність нашого дослідження. Мета розвідки полягає в дослідженні особливостей зображально-виражальних засобів у соціальній рекламі, контент якої спрямований проти винищення лісових ресурсів, виокремленні типових видів візуальних метафор, використаних у рекламних матеріалах на цю тему, та розкритті їх впливогенного потенціалу.

Методи дослідження. Для дослідження використані загальнонаукові методи аналізу й синтезу. Увага акцентувалася на зображальній складовій матеріалів, представлених 
у рекламних матеріалах, присвячених проблемі винищення лісових ресурсів. Контентаналіз для огляду використовуваних візуальних засобів та визначення тенденцій візуалізації екологічної проблематики в рекламних матеріалах, описовий метод дозволили виділити одиниці аналізу та класифікувати їх, компонентний та порівняльний аналізи дали можливість виділити типи рекламних візуальних метафор, зіставити їх за ступенем відвертості, емоційною складовою.

Результати дослідження й висновки. Проблема винищення лісових ресурсів планети, з огляду на актуальність і міжнародний статус, неодноразово ставала предметом соціальної реклами, що проводилася в окремих країнах. В основі впливогенності рекламних матеріалів лежить метафоричне осмислення дійсності, яке формують як вербальна, так і невербальна, візуальна складові. Утворюється так званий креолізований текст, в якому саме зображальна складова, що грунтується на візуальній метафорі, є основним носієм рекламного повідомлення, а текст допомагає його розкодуванню та підсилює впливогенний потенціал. Типовими метафорами в рекламах проти знищення лісу є зіставлення лісу й людського організму, лісу й життя його мешканців, а також гіперболізована візуалізація наслідків його знищення. Візуальний контент може бути значною мірою відвертим, жорстоким, апелювати до почуття провини й страху, що забезпечує впливогенність рекламних продуктів та є фактором ефективності таких рекламних кампаній.

Ключові слова: візуальна метафорика, зображально-виражальні засоби реклами, впливогенність реклали, креолізований текст, дизайн реклали.

Стаття надійшла до редакції 13.04.2021. 